\title{
Political Marketing in Macao
}

\section{A Solution to the Legitimacy Gap for a Hybrid Regime?}

\begin{abstract}
To what extent can political marketing narrow the legitimacy gap for a hybrid regime? This article examines this question through the case of Macao (2009-14). It finds that political marketing is insufficient to compensate for lack of democratic reform and may easily backfire to expose the problem of a structural legitimacy deficit.
\end{abstract}

KEYWORDS: political marketing, political legitimacy, democratization, hybrid regime, Macao

\section{INTRODUCTION}

Political marketing is a strategy widely adopted by democracies in campaigns and elections. ${ }^{1}$ With its demonstrated effects, ${ }^{2}$ it has been increasingly extended to a non-democratic context by rulers in authoritarian regimes and

Wilson Wong is Associate Professor in the Department of Government and Public Administration at the Chinese University of Hong Kong. YING-Ho Kwong is a Ph.D. student in the Department of Politics and Public Administration at the University of Hong Kong. The authors wish to thank Wing-yung Lai for research assistance and the anonymous reviewer for comments in preparing this article. Emails: <wwong@cuhk.edu.hk>, <yhkwong3@gmail.com>.

I. Shaun Bowler and David M. Farrell, "The Study of Election Campaigning," in Shaun Bowler and David M. Farrell, eds., Electoral Strategies and Political Marketing (New York: St. Martin's Press, 1992): I-23; Rudiger Schmitt-Beck and David M. Farrell, "Studying Political Campaigns and Their Effects," in David M. Farrell and Rudiger Schmitt-Beck, eds., Do Political Campaigns Matter? (New York: Routledge, 2002): I-2I; Pippa Norris, Electoral Engineering: Voting Rules and Political Behavior (New York: Cambridge University Press, 2004); Andre Blais, "Political Participation," in Lawrence LeDuc, Richard G. Niemi, and Pippa Norris, eds., Comparing Democracies 3: Elections and Voting in the 2Ist Century (London: Sage, 2010): 165-83; Christopher Wlezien, "Election Campaigns," in Comparing Democracies 3, 98-II7.

2. Peter Burnell and Andrew Reeve, "Persuasion as a Political Concept," British Journal of Political Science I4:4 (1984): 393-4IO; Pippa Norris, "Campaign Communications," in Lawrence LeDuc, Richard G. Niemi, and Pippa Norris, eds., Comparing Democracies 2: New Challenges in the Study of Elections and Voting (London: Sage, 2002): 127-47; Rudiger Schmitt-Beck and David M. Farrell, "Do Political Campaigns Matter? Yes, But it Depends," in Do Political Campaigns Matter? 183-93.

Asian Survey, Vol. 57, Number 4, pp. 764-789. ISSN oo04-4687, electronic ISSN 1533-838X. (C) 20I7 by The Regents of the University of California. All rights reserved. Please direct all requests for permission to photocopy or reproduce article content through the University of California Press's Reprints and Permissions web page, http://www.ucpress.edu/journals.php?p=reprints. DOI: https://doi.org/Io.I525/ AS.2017.57.4.764. 
in hybrid regimes (those with both democratic and authoritarian elements) to enhance the legitimacy of their government. Consistent with this trend, recent literature recognizes that modern Chinese leaders have used political marketing to build up their positive image and gain public support to maintain regime legitimacy. ${ }^{3}$ Many local governments at the province, county, and city levels in China have also adopted similar strategies to improve statesociety relations. ${ }^{4}$ In the Macao Special Administrative Region (MSAR), since assuming the office of chief executive in 2009, Fernando Chui Sai-on has followed in the footsteps of the central leaders and put political marketing at the core of his overall governing strategy. Under the former chief executive, Edmund Ho Hau-wah, the MSAR government faced heavy criticism ranging from charges of "corruption" to "black box operation" and lost legitimacy due to a series of political scandals. ${ }^{5}$ In response, after coming to office, Fernando Chui greatly expanded efforts using political marketing to reduce the legitimacy gap by designing the political brands of "sunshine government" and "scientific administration" to emphasize democratic elements for improving transparency, consultation, and deliberation.

In addition to winning public trust, maintaining political stability, and, ultimately, enhancing legitimacy, Chui aimed to use political marketing to reduce public pressure for major political reforms. His overall governing philosophy was consistent with the logic of the Chinese central government, which attached more importance to promising certain democratic elements (transparency, accountability, intra-party democracy, deliberation, and anticorruption) than to conducting any fundamental political reform. ${ }^{6}$

Does political marketing really work across political settings and regime types? The case of Macao leads to the important question: To what extent can

3. Yuezhi Zhao, "The Challenge of China: Contribution to a Transcultural Political Economy of Communication for the Twenty-First Century," in Janet Wasko, Graham Murdock, and Helena Sousa, eds., The Handbook of Political Economy of Communications (Oxford: Wiley-Blackwell, 20II): 558-82; Xiaoling Zhang, The Transformation of Political Communication in China: From Propaganda to Hegemony (Singapore: World Scientific, 20II); Siqi Zheng and Matthew E. Kahn, "Understanding China's Urban Pollution Dynamics," Journal of Economic Literature 5I:3 (2013): 731-72.

4. Zhendong Luo, Xu Wang, and Yi Hu, "Urban Scaling-Up and Endogenous Development Promoted by Continuous City Marketing: A Case Study of Xuyi County, China," Planning Theory I2:4 (2013): 406-24.

5. Sonny Shiu Hing Lo, "One Formula, Two Experiences: Political Divergence of Hong Kong and Macao since Retrocession," Journal of Contemporary China 16:52 (2007): 359-87, at 364 .

6. Joseph Fewsmith, The Logic and Limits of Political Reform in China (Cambridge: Cambridge University Press, 2013), 175. 
political marketing narrow the legitimacy gap of a government in a hybrid regime? This article addresses the question by examining the case of Macao under the government of Fernando Chui in his first term of office (2009-I4). It argues that political marketing alone is often insufficient to compensate for a lack of fundamental democratic reform because it is difficult for a nondemocratic or hybrid regime to imitate a democracy fully and deliver all its major qualities and performance outcomes. On the contrary, rather than enhancing legitimacy, the unfulfilled promises and unmet expectations generated by the political marketing of a hybrid regime can expose the structural problems of its undemocratic system. It can therefore lead to a further widening of the legitimacy gap and may even fuel the democratization movement.

Empirically, this paper adopts a political marketing perspective to account for the case of post-colonial Macao, considering empirical evidence. In the theoretical section, we explore the implications of adopting political marketing in a hybrid regime. First, we review the literature on political marketing from its application in campaigns in democracies to its use by governments of non-democratic regimes. Second, the paper discusses its application in Macao, including the political positioning of the MSAR and how Fernando Chui used the political brands of "sunshine government" and "scientific administration" and the appeal of democratic elements such as transparency, consultation, and deliberation in his attempts to enhance legitimacy. Finally, the effectiveness of political marketing in Macao and the implications of the analysis of Macao's governance for the study of comparative politics are discussed.

\section{POLITICAL MARKETING: FROM CAMPAIGNING IN DEMOCRACIES TO GOVERNING IN HYBRID REGIMES}

In the field of governance studies, political marketing has developed into an important theoretical perspective. ${ }^{7}$ By definition, political marketing refers to how political elites use marketing tools and concepts to understand, respond to, engage, and communicate with their political market. ${ }^{8}$ Political marketing has been extensively studied in the analysis of electoral campaigns in

7. Bruce I. Newman and Richard M. Perloff, "Political Marketing: Theory, Research and Applications," in Lynda Lee Kaid, ed., Handbook of Political Communication Research (Mahwah, NJ: Lawrence Erlbaum): I4-43.

8. Jennifer Lees-Marshment, Political Marketing: Principles and Applications (London: Routledge, 2OI3), 2. 
democracies in Europe and America. The mainstream studies focus on how candidates or political parties use marketing tools to communicate with voters to win elections. ${ }^{9}$ In the early stages, political campaigns tend to be episodic, and they are considered only a part of politics. ${ }^{10}$ As the field of political marketing evolves, politicians learn to campaign continuously to remain in office, especially by employing and generating positive imagery to maintain the growth and survival of their party, not simply to achieve victory in an election. ${ }^{11}$ Hence, political marketing should be not a shortterm tactical device used exclusively to win voters' support, but may be seen as a long-term permanent process aiming to ensure governance legitimacy and party continuity. Some scholars refer to this as a "permanent campaign." ${ }^{12}$ But it must not be forgotten that one of the important assumptions behind the above analysis is the existence of a democratic context with fair, open, and competitive elections.

Political marketing can contribute to a constructive relationship between political elites and society by maintaining stable support, building up public trust, and, more importantly, enhancing the legitimacy of a government. ${ }^{13}$ Specifically, many academic writers agree that one of the core areas of political marketing research is how politicians decide what to offer the public in relation to public demands. ${ }^{14}$ It is also important to discuss how governments plan, design, and take action to achieve their political objectives. In

9. Philip Kotler and Sidney J. Levy, "Broadening the Concept of Marketing," Journal of Marketing 33:I (1969): I0-15; Philip Kotler and Neil Kotler, "Political Marketing: Generating Effective Candidates, Campaigns and Causes," in Bruce I. Newman, ed., Handbook of Political Marketing (Thousand Oaks, CA: Sage, 1999); Phil Harris, "Machiavelli, Political Marketing and Reinventing Government," European Journal of Marketing 35:9/10 (200I): II36-54.

Io. Stephan C. Henneberg and Nicholas J. O'Shaughnessy, "Theory and Concept Development in Political Marketing," Journal of Political Marketing 6:2/3 (2007): 5-31.

II. Gary A. Mauser, Political Marketing: An Approach to Campaign Strategy (New York: Praeger, 1983), II-I4.

I2. Dan Nimmo, "The Permanent Campaign: Marketing as a Governing Tool," in Newman, Handbook of Political Marketing, 73-86; Gareth Smith and Andy Hirst, "Strategic Political Segmentation: A New Approach for a New Era of Political Marketing," European Journal of Marketing 35:9/ Io (200I): I058-73; Phil Harris and Andrew Lock, "Mind the Gap': The Rise of Political Marketing and a Perspective on its Future Agenda," European Journal of Marketing 44:3/4 (2010): 297-307.

I3. Jennifer Lees-Marshment, The Political Marketing Game (New York: Palgrave Macmillan, 20II), I2-I5.

I4. Jennifer Lees-Marshment, "Conclusion: New Directions in Political Marketing Practice, Political Marketing and Democracy, and Future Trends," in Jennifer Lees-Marshment, ed., Routledge Handbook of Political Marketing (New York: Routledge, 20I2): 368-88, at 370. 
this context, political marketers usually adopt an analytical framework of three phases: (I) political positioning — using market analysis to identify the political problem; (2) political brand-building-establishing the political brand to match the expectations of society; and (3) marketing implementationdelivering their products in practice to maintain public support. ${ }^{15}$ These three phases will be applied later in the case of Macao.

However, political marketing has its own limitations. The concept is closely linked to psychological factors such as society's perceptions and degree of satisfaction. Politicians must know what society wants from them, and deliver actual policies to achieve their political goals. This mechanism is fundamental to political marketing and critical for the legitimacy of government. Misuse of political marketing strategy, such as a mismatch with expectations or the outbreak of political scandal, leading to a sharp contrast between promises and reality, might increase public distrust and further weaken legitimacy. ${ }^{16}$ In such cases, society can demand the removal of political leaders, or more seriously, push for fundamental and comprehensive reforms as structural problems in the political system are exposed.

Witnessing the success of political marketing in democracies, leaders of authoritarian and hybrid regimes have started to borrow the approach to benefit their own governing. As mentioned by Mauser, "almost all politicians use marketing techniques and ideas, but very few wish to admit it openly." ${ }^{\prime 17}$ There are increasing numbers of studies whose writers are interested in how non-democratic governments apply political marketing to respond to public demands. Shestopal, Pishcheva, Gikavyi, and Zorin conducted a quantitative survey in Russia and found that President Vladimir Putin has successfully built up an image of strong leadership that matches mass expectations. Citizens had formed a favorable view of Putin's performance and were willing to follow and believe in him, which led to fewer political conflicts with the government. ${ }^{18}$ Lee and Willnat examined Singapore and argued that the ruling People's Action Party applied political marketing to package itself as a strong, united government that provides economic and social achievement,

15. Lees-Marshment, Political Marketing Game, 45.

I6. Ibid, 217.

17. Mauser, Political Marketing, 83.

I8. Elena Borisovna Shestopal, Tat'iana Nikolaevna Pishcheva, Evgenii Miroslavovich Gikavyi, and Vasilii Anatol'evich Zorin, "The Image of V.V. Putin in the Consciousness of Russia's Citizens," Sociological Research 43:6 (2004): 29-56. 
while attacking the opposition as irresponsible opportunists. This strategy brought a high level of credibility and legitimacy to the party in the short run. In the long run, however, the people of Singapore grew uncomfortable with tight political and social control and began to demand political reforms. ${ }^{19}$

Studies of political marketing have also covered China and Hong Kong. Sun, for instance, discovered Chinese applications of political marketing, including image-building for the Chinese Communist Party and top leaders designed to gain public support and, more important, ensure regime survival. ${ }^{20}$ Fong examined the case of Hong Kong and pointed out that Donald Tsang, its second chief executive, adopted political marketing to brand his governance as "pragmatic leadership." Fong found that political marketing campaigns helped Tsang maintain a high popularity rating in the beginning, but that he lost support later as the structural legitimacy deficit under the existing semi-democratic regime of Hong Kong was further exposed. ${ }^{21}$

To sum up, the results of political marketing in non-democratic or hybrid regimes tend to be mixed, often showing a positive short-term effect that is followed by a relatively negative long-term effect. It appears that political marketing is a double-edged sword. Effective political marketing creates a positive image of the government, ${ }^{22}$ contributing to political credibility ${ }^{23}$ and building up a positive society-government relationship, ${ }^{24}$ but its failure can also lead to anger toward and discontent with the political leaders-as well as with the system governing how those leaders are selected. The findings so far tend to suggest a working proposition that the positive effects of political marketing in non-democracies may have to be accompanied by other

19. Terence Lee and Lars Willnat, "Media Management and Political Communication in Singapore," in Lars Willnat and Annette Aw, eds., Political Communication in Asia (New York: Routledge, 2009): 93-III.

20. Henry H. Sun, "International Political Marketing: A Case Study of Its Application in China," Journal of Public Affairs 7:4 (2007): 331-40, at 336.

2I. Brian C. H. Fong, "Political Marketing Campaigns of Chief Executive Donald Tsang: The Challenges of Managing Legitimacy Deficit under a Semi-democratic Regime," in Joseph Y. S. Cheng, ed., The Second Chief Executive of Hong Kong SAR: Evaluating the Tsang Years 2005-20I2 (Hong Kong: City University of Hong Kong, 2013): $\mathrm{II}_{3}-38$.

22. Darren G. Lilleker, "Political Marketing: The Cause of an Emerging Democratic Deficit in Britain?" in Walter W. Wymer Jr. and Jennifer Lees-Marshment, eds., Current Issues in Political Marketing (New York: Haworth Press, 2013): 5-26, at 23.

23. Darren G. Lilleker and Nigel Jackson, "Political Public Relations and Political Marketing," in Jesper Strömbäck and Spiro Kiousis, eds., Political Public Relations: Principles and Applications (New York: Routledge, 20II): 157-76, at 164 .

24. Lees-Marshment, Political Marketing, 7. 
structural and reinforcing factors, such as the establishment of wellfunctioning institutions and actual structural reforms meeting public expectations, for the positive effects to be sustainable. This proposition will be further examined in this case study of Macao.

\section{POLITICAL POSITIONING: IDENTIFYING THE LEGITIMACY GAP IN THE HYBRID REGIME OF MACAO}

The political system of the MSAR can be described as a hybrid regime: a mixture of democratic and undemocratic elements. ${ }^{25}$ In contrast to the British government's plan for Hong Kong (the other SAR), during the handover negotiation period the Portuguese government did not insist on promoting democratization in Macao, due to consideration of the Chinese market and reactions of the Chinese government. ${ }^{26}$ The Macao Basic Law, the mini-constitution of Macao, clearly reflects the Beijing government's lack of enthusiasm for democratization there, when compared with Hong Kong. According to Article 45 of the Hong Kong Basic Law, the ultimate goal of the chief executive election is selection by universal suffrage. There is no such commitment in the Macao Basic Law. ${ }^{27}$ Similarly, there is nothing like Article 68 of the Hong Kong Basic Law, stipulating the ultimate goal of election of all legislators by universal suffrage. The Basic Law of Macao only states that the majority of the legislators shall be "elected." 28 In fact, the selection of the chief executive and the legislators is dominated by proBeijing forces. Currently, the chief executive is elected by a $400-$ member election committee, whose members are selected by pro-Beijing associations. In the Legislative Assembly, the pro-Beijing forces have fully controlled the indirect seats through those pro-China groups and appointed enough seats through nominations of the chief executive to gain an absolute majority.

25. Eilo Wing Yat Yu, "Executive-Legislative Relationships and the Development of Public Policy," in Newman M. K. Lam and Ian Scott, eds., Gaming, Governance and Public Policy in Macao (Hong Kong: Hong Kong University Press, 20II): 57-74, at 73; Mathew Y. H. Wong, "Party Models in a Hybrid Regime: Hong Kong 2007-2012," China Review I5:I (2015): 67-94; Ying-ho Kwong, "Ruling Coalition Restructuring under Macao's Hybrid Regime," China Review (forthcoming).

26. Sonny Shiu Hing Lo, Political Development in Macau (Hong Kong: Chinese University Press, 1995), 23; Wai-man Lam, "Political Context," in Wai-man Lam, Percy Lui, and Wilson Wong, eds., Contemporary Hong Kong Politics (Hong Kong: University of Hong Kong Press, 20I2): I-22, at 3.

27. Yash Ghai, "The Basic Law of the Special Administrative Region of Macau: Some Reflections," International and Comparative Law Quarterly 49:I (2000): I83-98, at I9I.

28. Ibid., I9I. 
Therefore, the general public is either excluded or marginalized from selecting their chief executive and a large number of members in the legislature, although various civil liberties have been guaranteed for Macao under the Basic Law. In maintaining certain civil liberties and some limited elements of democratic elections, Macao should be classified as a hybrid regime.

Fernando Chui was the only candidate in the chief executive election in 2009. Even so, due to the weak procedural legitimacy of the Macao government and the declining legitimacy inherited from his predecessor, Edmund Ho Hau-wah, Chui had an urgent need to provide better performance as soon as he assumed office. One of his main aims was to improve state-society relations and enhance legitimacy through political marketing. In political marketing, political positioning is the first step in assessing where a government or politician is in relation to the public and considering how to respond to them. In choosing their political positioning, the political elite resembles merchants selling hope to "targeted customers." 29 As the head of Macao, the chief executive has to serve at least two "customers": the nation of China and the Macao people. On the one hand, the chief executive had to design political strategies to show his capacity to govern, his loyalty, and his commitment to the Chinese leaders. On the other hand, he needed to win public support in Macao. The political positioning adopted by Fernando Chui can be analyzed as a series of responses designed to simultaneously please the Chinese leadership and the Macao people.

With the announcement of the Scientific Outlook on Development in 2003, former Chinese President $\mathrm{Hu}$ Jintao launched a series of new policies to improve the governance capacity of local governments; one of the key policies was the Sunshine Law. On January 17, 2007, the State Council promulgated the Regulation of the People's Republic of China on the Disclosure of Government Information at its 165th executive meeting; it came into force May I, 2008. This regulation, according to Article I, is designed to protect legal access to government information by citizens, legal persons, and other organizations; improve the transparency of government work; promote administration according to law; and give full play to the role of government information in serving the people's production, living, and social and economic activities. Under the principle of One Country, Two Systems, the MSAR

29. Wojciech Cwalina, Andrzej Falkowski, and Bruce I. Newman, Political Marketing: Theoretical and Strategic Foundations (Armonk, NY: M.E. Sharpe), I6. 
government had no obligation to implement this regulation, but Fernando Chui still put some of its principles into his first policy address. Presumably, he wished to show that he was following national policy direction and could implement those policies in the MSAR, assuring the central leaders that he was a good choice. ${ }^{30}$

Chui's predecessor Edmund Ho, who took office in 1999, enjoyed a high level of satisfaction from the local community in his first term (19992005). The turning point of the decline of legitimacy under his leadership came in his second term, after a series of policy failures, corruption cases, and political scandals. Overspending for the East Asian Games and the case of Ao Man-long were two significant cases that exposed the problems of "black box operation" and "unclean government" in Macao. ${ }^{31}$ On November 2, 2006, the Commission of Audit released an investigative report on the Fourth East Asian Games, which had been held in late October 2005. The report found that the MSAR government spent around 4.4 billion Macanese patacas (MOP) (US\$ 550 million) to hold the games, exceeding the budget by $50.6 \% .^{32}$ This sparked outrage from legislators, especially opposition ones, and public concern regarding the waste of public money, poor budget planning, and lack of public oversight and accountability of the MSAR government. Many commentators also criticized the "black box decision-making" and non-transparency of the Macao government. $^{33}$

Another major case was the corruption scandal of Ao Man-long in 2006. Ao, the former secretary for transport and public works, was bribed by contractors and land developers to use his discretionary power to favor their companies with government projects and grants of government land. ${ }^{34}$ Ao was arrested, found guilty, and sentenced to 27 years for taking bribes and

30. Jiazeng Li, "Yangguang zhengfu de benzhi tezheng yu Aomen tequ zhengfu de nuli fangxiang" [Essential Characteristics of a "Sunshine Government" and the Future Direction for the Macao SAR Government], in Wan Chong Ieong, ed., Yangguang Zhengfu yu Gongmin Shehui Jianshe Xueshu Yantaohui Lunwen Ji [Conference Paper of Sunshine Government and Civil Society Development] (Macao: One Country Two Systems Research Centre, 2010): 28-36, at 28-29.

31. Eilo Wing-Yat Yu, "Formal and Informal Politics in Macao Special Administrative Region Elections," Journal of Contemporary China I6:52 (2007): 4I7-4I.

32. "Dongyayun 44 yi hunzhang" [Confusing Budget of East Asia Games], Macao Daily News, November 2, 2006, PoI.

33. Lo, "One Formula, Two Experiences," 364.

34. Eilo Wing-Yat Yu, "Anti-Corruption Approaches in Macao: Lawmaking and Legal Enforcement," Journal of Contemporary China 22:79 (2013): 93-108. 
laundering money worth MOP 800 million (US\$ Ioo million). ${ }^{35}$ This scandal was described as "the most serious corruption of the century," and it greatly damaged the legitimacy of Ho's government. Public grievances and anger sent the people of Macao out into the streets to protest Ho's poor governance. On May I, 2007, IO,000 demonstrators joined a protest against the MSAR government, and a police officer fired three shots into the air during a confrontation between police and protesters, shocking the entire territory. ${ }^{36}$ After that, the May First protest became a major annual event expressing local distrust and disapproval of the MSAR government. All these policy failures undermined public confidence in Ho's governing capacity and generated widespread dissatisfaction and frustration in the local community. ${ }^{37}$

In general, surveys showed a decline of legitimacy under Edmund Ho's governance (Figure I). In his first term (2000-05), net satisfaction was stable and high, at 60\%-70\%. It averaged 60\%-80\% most of the time, and less than Io $\%$ were dissatisfied. However, the situation changed during his second term (2006-IO) after a series of political scandals and massive demonstrations. Between 2006 and 2007, satisfaction fell sharply, and Ho never regained his popularity. Opinion surveys showed the number of people dissatisfied with his overall performance increased incrementally, while the number satisfied became unstable. Edmund Ho's second term reflected a decline in legitimacy; it was crucial for Chui to stop the decline and find a way to recover.

Specifically, public opinion polls indicated that a large number of respondents demanded a more transparent government in Macao. Some $65 \%$ demanded the establishment of a "sunshine government" to improve transparency, which people considered the first priority for the new Fernando Chui administration. ${ }^{38}$ Also, the Macao people have long considered public consultation one of the most important elements of a government. ${ }^{39}$ These

35. Bill K. P. Chou, "Implementation Measures of China's Macao Policies," Chinese Law and Government 45:5 (2012): 3-9, at 3.

36. Sonny Shiu Hing Lo, Political Change in Macao (London: Routledge, 2008), 65.

37. C. S. Bryan Ho, "Political Culture, Social Movements, and Governability in Macao," Asian Affairs 38:2 (20II): 59-87.

38. One Country Two Systems Research Institute, "Yangguang zhengfu yu yangguang shehui" [Sunshine Government and Sunshine Society], Research on One Country Two Systems 7 (2010): 4I-57, at $4 \mathrm{I}$.

39. Herbert Yee, Sheng Hua Lou, and Cheuk Wah Chan, Aomen Huaren Zhengzhi Zongxiang Yanjiu [Longitudinal Research on the Political Culture of Macao] (Hong Kong: Joint Publishing (HK), 20II), 95. 
FIgURe I. People's Satisfaction with Overall Performance of the MSAR Government, I999-20I4

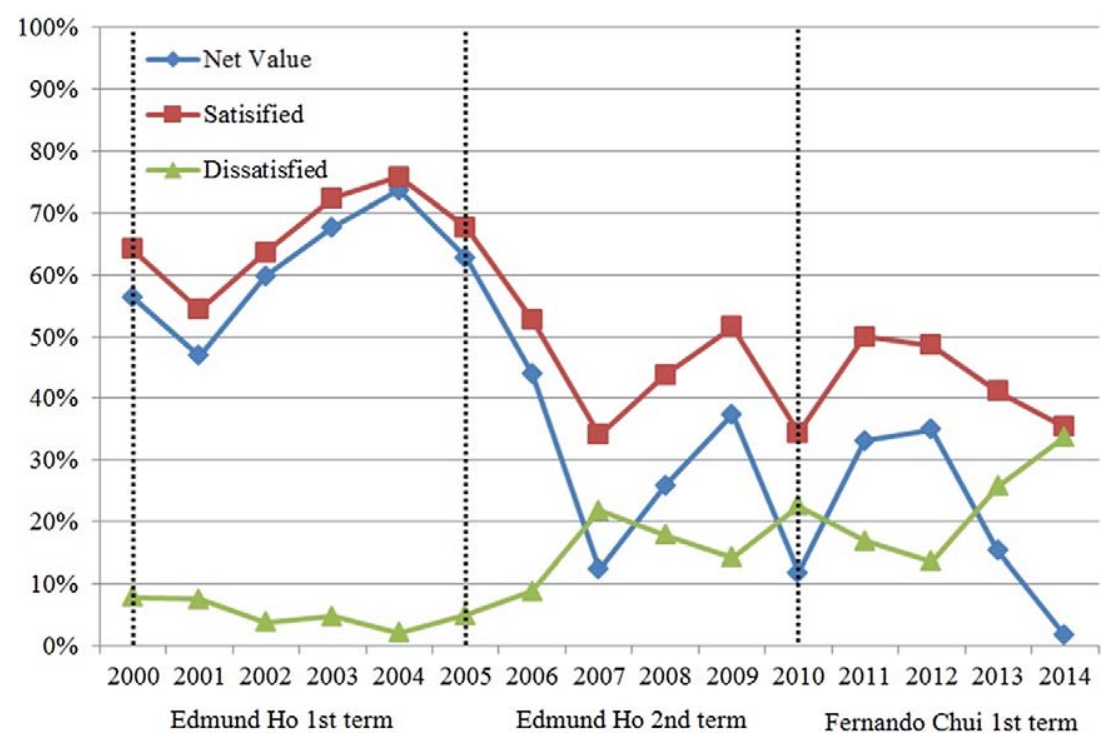

SOURCE: "Survey on Public Satisfaction with the Overall Performance of MSAR Government," Public Opinion Program, University of Hong Kong, December 19, 20I4, <http://hkupop.hku.hk/chinese/ popexpress/macau/govSat/datatables.html>, accessed December 20, 2014.

expectations played a decisive role in influencing the political positioning of Chui's government.

\section{POLITICAL BRAND-BUILDING: "SUNSHINE GOVERNMENT" AND "SCIENTIFIC ADMINISTRATION"}

Fernando Chui assumed office on December 20, 2009 facing the urgent task of restoring public support and legitimacy post-Edmund Ho. Ho was originally perceived as an effective leader, well honed for political leadership under the wing of his late father, Ho Yin, a long-time leader of the Chinese community in Macao. ${ }^{40}$ Chui and his family also held a leading role in the Chinese community and were trusted political allies of Beijing. However,

40. Alex H. Choi, "Intergovernmental Relations between Mainland China and the Macao SAR," in Evan M. Berman, ed., Public Administration in Southeast Asia: Thailand, the Philippines, Malaysia, Hong Kong, and Macao (New York: CRC Press, 20II): 475-99, at 48I. 
table I. Political Marketing Activities in Macao, from Handover to December 19, 2014

\begin{tabular}{lccc}
\hline & $\begin{array}{c}\text { Edmund Ho } \\
\text { Ist term } \\
\text { Political marketing activities }\end{array}$ & $\begin{array}{c}\text { Edmund Ho } \\
\text { 2nd term } \\
\text { (Dec. 2004-09) }\end{array}$ & $\begin{array}{c}\text { Fernando Chui } \\
\text { Ist term } \\
\text { (Dec. 2009-I4) }\end{array}$ \\
\hline Media sessions & 78 & 76 & 145 \\
Public speeches & 97 & 120 & 154 \\
Community visits & 30 & 29 & 39 \\
Total & 205 & 225 & 338 \\
\hline
\end{tabular}

SOURCE: Authors' analysis, based on information from the Chief Executive Office (http://www.gce.gov. mo) and the Government Information Bureau (http://www.gcs.gov.mo).

given the declining legitimacy and the changing political circumstances in Macao, a simple political brand of a strong and traditional leader trusted by Beijing was no longer sufficient. Starting with his election campaign, Chui promised to establish an open, transparent, and deliberative government.

Consistent with his political marketing strategy, Chui made use of various methods to interact with the public to explain his policies, including holding media sessions, delivering public speeches, and conducting community visits. Table I compares the political marketing activities of Ho and Chui. Fernando Chui was obviously more active. He continued his brand-building after being re-elected in 20I5, when he made I4 public speeches, held 35 press conferences or media sessions, and undertook seven community visits and social activities.

With this increased and active communication with society, Chui attempted to imprint his "political brands" in the minds of the Macao people. Political branding provides a summary for the public of the government's image. ${ }^{41}$ To construct a positive relationship and address the public concerns raised during his predecessor's administration, Chui designed two political brands, "sunshine government" and "scientific administration," to integrate his political philosophy and satisfy public demand.

Chui also presented his ideas in his first policy address in 2010 and expounded his political message, defining "sunshine government" and "scientific administration." With regard to "sunshine government," Chui expressed his belief that:

4I. Kenneth M. Cosgrove, "Political Branding in the Modern Age: Effective Strategies, Tools and Techniques," in Lees-Marshment, Routledge Handbook of Political Marketing, 107-23, at 107. 
Using official websites of different departments and media means, the government has to provide adequate information accessibility and more communication channels to accept monitoring by both the public and the mass media. Furthermore, we will establish the Office of the Government Spokesman to offer regular information and news announcement sessions. We want to protect the right of the public to information, better explain policy proposals to them, and enhance our policy coordination with society. By improving policy effectiveness and transparency, we can achieve the target of public affairs accessibility and establish a "sunshine government." ${ }^{2}$

From this point of view, the key to "sunshine government" was enhancing both transparency and the accessibility of government information by offering more platforms to the public. Chui also spoke of "scientific administration":

Scientific administration is an important method to enhance governance capacity. In the policymaking process, we need to broaden our mind, collect public opinions, and listen to different sectors to achieve democratic decisionmaking. Hence, the MSAR government will set up an Office of Policy Research, which is accountable to the Chief Executive for conducting consultations, assisting different policy bureaus, and facilitating the Chief Executive in comprehending public opinion. ${ }^{43}$

In this address, the core concept of "scientific administration" refers to an emphasis of government on conducting consultations and incorporating public opinion into policymaking. After the announcement of his political brands, Chui made use of every public occasion to present and restate them. Table 2 shows that "consultative" and "sunshine" government are the repeated themes of Chui's political rhetoric. When he attends media sessions, delivers public speeches, and gives policy addresses, he frequently uses the words "scientific" or "consultative" and "sunshine" or "transparent" to promote his political brand and establish an image of his governing style firmly in the minds of the Macao people.

In his new term beginning in 20I4, promoting these two political brands remained an important task. In 20I5, Chui used the words "scientific" and "consultation" I3 times and the words "transparency" and "sunshine" four times in marketing events. Similarly, he always used the policy address as an

42. Authors' translation. Macao SAR Government, Policy Address for the Fiscal Year 2010 (Macao, 2010), 33-34.

43. Authors' translation. Ibid, 22. 
table 2. Content Analysis of Fernando Chui's Political Branding, from Handover to December 19, 2014

\begin{tabular}{lccc}
\hline & $\begin{array}{c}\text { Fernando Chui } \\
\text { Ist term } \\
\text { (Dec. 2009-I4) }\end{array}$ & $\begin{array}{c}\text { Occurrence of } \\
\text { keywords "scientific" } \\
\text { and "consultation" }\end{array}$ & $\begin{array}{c}\text { Occurrence of } \\
\text { keywords "sunshine" } \\
\text { and "transparency" }\end{array}$ \\
\hline Political marketing activities & 5 & 389 & 90 \\
Media sessions & $\mathrm{I} 45$ & 35 & $\mathrm{I} 2$ \\
Public speeches & $\mathrm{I} 54$ & 70 & $4 \mathrm{I}$ \\
Total & 304 & 494 & $\mathrm{I} 43$ \\
\hline
\end{tabular}

SOURCE: Authors' analysis, based on information from the Chief Executive Office (http://www.gce.gov. mo), Government Information Bureau (http://www.gcs.gov.mo), and Policy Address (http://www. policyaddress.gov.mo/policy/home.php?). The essence of the content analysis was to scan all the political rhetoric made by Edmund Ho and Fernando Chui and then to determine the frequency of the keywords "scientific" (ke xue), "consultation" (zi xun), "sunshine" (yang guang), and "transparency" (tou ming) in the political rhetoric of each.

important platform to bolster his brands. In 20I5, he mentioned "scientific" and "consultation" Io6 times, and "transparency" and "sunshine" I3 times, in this document.

\section{POLITICAL MARKETING IMPLEMENTATION: STRENGTHENING TRANSPARENCY AND DELIBERATION}

Chui created a series of policies to implement these political brands and realize his ruling philosophies. To begin with, he set up the Office of the Government Spokesman to speed up policy responses to the public and establish a communication mechanism with the media. ${ }^{44}$ The MSAR government further committed to the creation of more resources for personnel training and to delivering administrative and emergent information to the public more actively to increase access to and release of government information. ${ }^{45}$ Since its establishment, the office has made more than 270 announcements, including via press conferences, press releases, and media sessions.

Second, the administration continued to press for greater transparency in other areas, notably the income and interests of high-ranking officials. In 
2003, the Hong Kong South China Morning Post revealed that Edmund Ho was one of the shareholders of a listed company but had failed to report his profits in accordance with the Patrimonial Declaration of Incomes and Interests. Because of his special status, he was not investigated or charged by any department. ${ }^{46}$ But the public was deeply disappointed. Learning from Ho's lesson, Chui reformed the former Declaration of Incomes and Interests system to the Legal Regime of Declaration of Assets and Interests (a new sunshine law) to meet the public expectation. High-ranking officials, including the chief executive and principal officials, executive councilors, legislators, and so on, must declare their assets and interests for public scrutiny. ${ }^{47}$ Offering this system of open information from 20I3, Chui believed he could improve the image of government and regain public trust.

Third, on August 5, 20II, he implemented the Guideline on Policy Consultation Regulations, which aimed to enhance the quality of consultations for public participation in governance. "Consultation" for Chui refers to setting a formal mechanism to collect public opinion, and the guideline set up several important principles for future consultation. It required various government departments to release consultation information, to establish a convenient platform for information delivery and collection, and to strengthen interaction among consultative committees, different social organizations, and stakeholders, with the ultimate goal of improving transparency and responsiveness. ${ }^{48}$ Based on those principles, government departments would conduct consultations and collect public opinion on their policymaking. Table 3 surveys the number of published consultation documents issued by Edmund Ho and Fernando Chui since Handover. The number published by Chui's administration is nearly double that published during Ho's second term. It appears that Chui is courting an image of being an open-minded leader who welcomes public opinion and discussion. Since his re-election in 20I4, the emphasis on consultation has remained crucial. In 20I5, the MSAR government released I4 consultation documents.

Interest group politics is a major characteristic of the government of Macao because pro-China groups, especially business chambers, labor unions, and

46. Bruce K. K. Kwong, "Public Ethics and Corruption in Macao," in Berman, Public Administration in Southeast Asia, 50I-I8, at $5 \mathrm{I} 3$.

47. Commission against Corruption, "Declaration of Assets and Interest: Related Issues," $<$ http://www.ccac.org.mo/dbpi/index_e.html>, accessed December I5, 2014 .

48. Macao SAR Government, Policy Address for the Fiscal Year 2012 (Macao, 20II), I38. 
table 3. Content Analysis of Published Consultation Documents, from Handover to December 19, 2014

Edmund Ho Ist term (Dec. 1999-2004)

Edmund Ho 2nd term (Dec. 2004-09)

Fernando Chui Ist term (Dec. 2009-I4)

53

SOURCE: Authors' analysis, based on information from Policy Consultation (http://portal.gov.mo/web/ guest/info_detail?infoid=9II43) and the Government Information Bureau (http://www.gcs.gov.mo).

grass-roots associations, have influenced policy outcomes. ${ }^{49}$ The MSAR government has held regular meetings and consulted these special interest groups to understand their stances and needs. According to political scientist Eilo Yu, Edmund Ho, as a leader who emphasized rule by virtue and strong leadership, made good use of "informal politics," i.e., cronyism or guanxi [connections] networks, to resolve sociopolitical conflict and tensions. ${ }^{50}$ However, these types of networks have been denounced as "black box operations" because the general public was mostly uninformed and excluded. ${ }^{51}$

As interest group politics endured within Macao's governance, Chui deftly packaged it as "open" and publicly announced activities under his brand of "sunshine government." In the Ho era, these meetings and discussions between the chief executive and various interest groups were less likely to be mentioned in official news releases. But Chui used the concept of focus group discussions and openly announced invitations to various social groups for in-depth consultation and discussion, reducing the perception that he was using "black box operations." As shown in Table 4, Chui announced such meetings more frequently than did Ho. Indeed, not only pro-Beijing associations and representatives, but also opposition groups were annually invited by Chui to share their opinions. This kind of group meeting continued to be used in 20I5 and 2016: 54 and 37 focus group meetings were reported on the official website for these years, respectively.

49. Bill K. P. Chou, "Interest Group Politics in Macau after Handover," Journal of Contemporary China I4:43 (2005): I9I-206, at 19I-92; Choi, "Intergovernmental Relations," 489.

50. Yu, "Formal and Informal Politics," 44I.

5I. Ibid., 436-37. 
table 4. Content Analysis of Reported Focus Group Discussions in Macao, from Handover to December 19, 2014

Term

Number of reported focus group discussions

Edmund Ho Ist term (Dec. 1999-2004)

IO

Edmund Ho 2nd term (Dec. 2004-09)

2I

Fernando Chui Ist term (Dec. 2009-I4)

SOURCE: Authors' analysis, based on information from the Chief Executive Office (http://www.gce.gov. mo) and the Government Information Bureau (http://www.gcs.gov.mo).

\section{POLITICAL MARKETING AND PERFORMANCE-BUILDING: OLD} WINE IN A NEW BOTTLE?

Given the non-democratic nature of the MSAR, as in many hybrid regimes, any chief executive-not just Edmund Ho or Fernando Chui-would have to rely heavily on "performance legitimacy" to maintain the governability of Macao. Lo and Yee found that Edmund Ho used civil service reform and new constitutional conventions in his attempt to address the public maladministration of the Portuguese colonial government and improve the image of the MSAR government. ${ }^{52}$ Chou draws a similar conclusion in his study of the MSAR government, concluding that it relied on public-sector reforms to provide administrative efficiency and on performance to tackle political problems. ${ }^{53}$ Eilo Yu discussed the MSAR government's reform of anticorruption measures to present an image of clean government to enhance its legitimacy. ${ }^{54}$

This political formula of promising the introduction or delivery of some piecemeal democratic elements such as anti-corruption, accountability, or efficiency in government performance to replace structural political reform is commonly used by non-democratic regimes to enhance their legitimacy and maintain the continuity of their rule. ${ }^{55}$ Expanding a certain number of democratic elements fulfills a myriad of political functions, which include

52. Sonny S. H. Lo and Herbert S. Yee, "Legitimacy-Building in the Macau Special Administrative Region: Colonial Legacies and Reform Strategies," Asian Journal of Political Science I3:I (2005): $5 \mathrm{I}-79$.

53. Bill K. P. Chou, "Legitimacy-Building and Public Sector Reform in Macao: Administrative Measures to Address Political Problems," China: An International Journal IO:3 (2012): 133-48, at I33.

54. Yu, "Anti-Corruption Approaches."

55. Jennifer Gandhi, Political Institutions under Dictatorship (Cambridge: Cambridge University Press, 2010). 
displaying an internationally positive image, ${ }^{56}$ enhancing government legitimacy, ${ }^{57}$ dividing the power of opposition forces, ${ }^{58}$ and buying time to postpone full democracy. ${ }^{59}$ This strategy was also adopted in mainland China by the Chinese central government. Fewsmith concluded that the governing strategy of China could be characterized as still mainly one of "consultative authoritarianism," which fulfills only a showcase function while avoiding institutional reforms. ${ }^{60}$

Macao, as an SAR of China, followed the same governance logic: it promised to build a "sunshine government" and "scientific administration" to expand a certain number of democratic elements, but resisted any major political reform. Although Fernando Chui intended to use political marketing to gain public support, public satisfaction did not rise but fell even further. Figure 2 shows the number of social movements, such as protests, sit-ins, and assemblies, reported by local newspapers since Handover. It was evident that the overall trend of reported social movements was increasing and people were more participative in the expression of their dissatisfaction through collective action in areas ranging from specific labor to welfare policies. People were also more active in joining protests in favor of more democratic reform generally. Except for the first year of Chui's administration, which may be taken as a honeymoon period, the trend of increasing numbers of social movements seen under Ho's administration (2000-09) continued under Chui's second administration (20IO-I4). In other words, the public was increasingly dissatisfied with many political and social issues, and the decline in government legitimacy was never reversed.

It is often tough for an authoritarian or hybrid regime to deliver performance outcomes and provide democratic elements, including respect for civil rights and toleration of liberty, without the necessary corresponding structural reforms. Even worse, frequent promises to expand or introduce certain democratic elements in authoritarian regimes will further raise public expectations of

56. Staffan I. Lindberg, "Introduction," in Staffan I. Lindberg, ed., Democratization by Elections: A New Mode of Transition (Baltimore, MD: Johns Hopkins University Press, 2009): I-2I.

57. William Case, "Hybrid Politics and New Competitiveness: Hong Kong's 2007 Chief Executive Election," East Asia 25:4 (2008): 365-88, at 365.

58. Andreas Schedler, "Sources of Competition under Electoral Authoritarianism," in Lindberg, Democratization by Elections, 179-245.

59. Marina Ottaway, Democracy Challenged: The Rise of Semi-Authoritarianism (Washington, DC: Carnegie Endowment for International Peace, 2003).

6o. Fewsmith, Logic and Limits, 175 . 
FIGURE 2. Number of Reported Social Movements outside the MSAR Government's Office

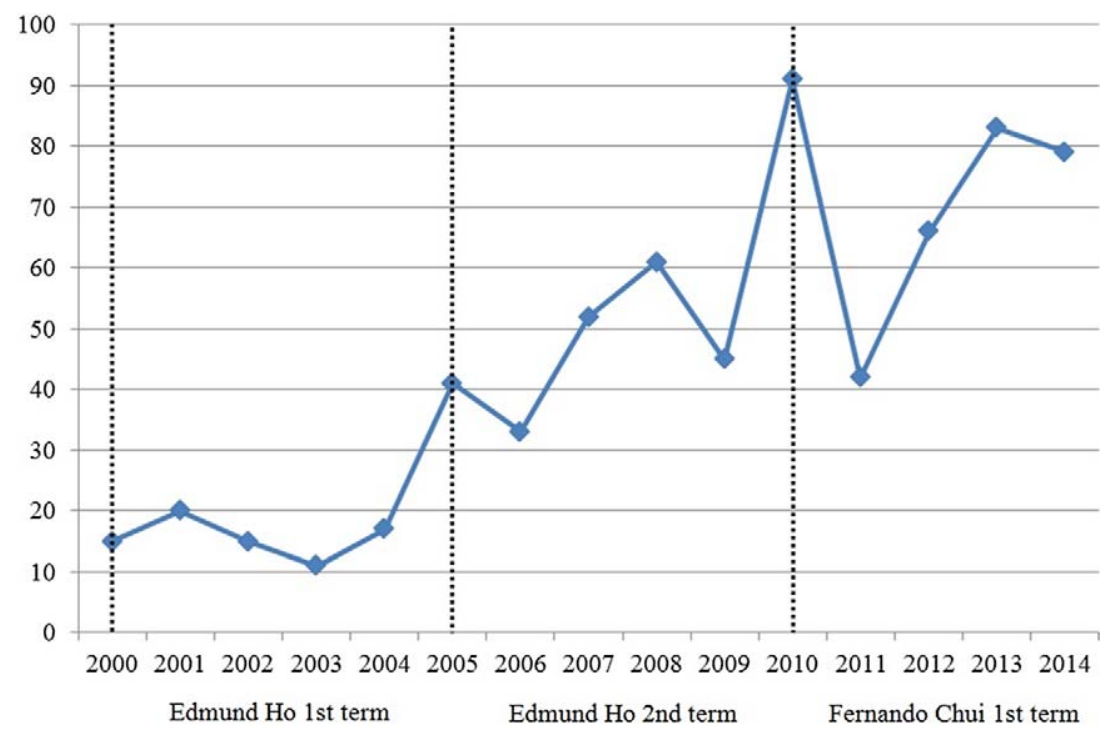

SOURCE: Authors' analysis, based on the information obtained from the WiseNews electronic database. The research conducted counted the number of newspaper reports that mentioned social movements in Macao from 2000 to 20I4. The local newspapers covered in this research are Exmoo News, Hou Kong Daily, Jornal Cheng Pou, Shimin Daily, Jornal Informação, Jornal San Wau Ou, Jornal Va Kio, Macao Daily News and Tai Chung Pou.

full democracy, or at least something closer to it. When the public realizes that an authoritarian regime is making false and insincere promises, they might feel frustrated and angry, which may consolidate and deepen their desire for comprehensive political reform.

In Macao, on the one hand, Chui's carefully designed political marketing strategies did not address the problem of the structural legitimacy deficit under the current political system. On the other hand, as new policies focused more on public relations than on policy substance, the lack of authentic improvement in performance further increased public dissatisfaction with the MSAR government (Figure I). Clearly, by 20I3 satisfaction with Chui was even lower than with Edmund Ho. Political marketing did not help Chui regain public support or raise it to the level enjoyed by Ho's administration.

In 20I4, net satisfaction, the difference between positive and negative ratings, broke a record, falling to only 1.6\%. Although the value increased a bit, to $6 \%$, in 2015 , the alarm is still sounding. Figure 3 shows public satisfaction with the 
FIGURE 3. People's Satisfaction with the MSAR Government's Performance on the Pace of Democratic Development, 1999-20I4

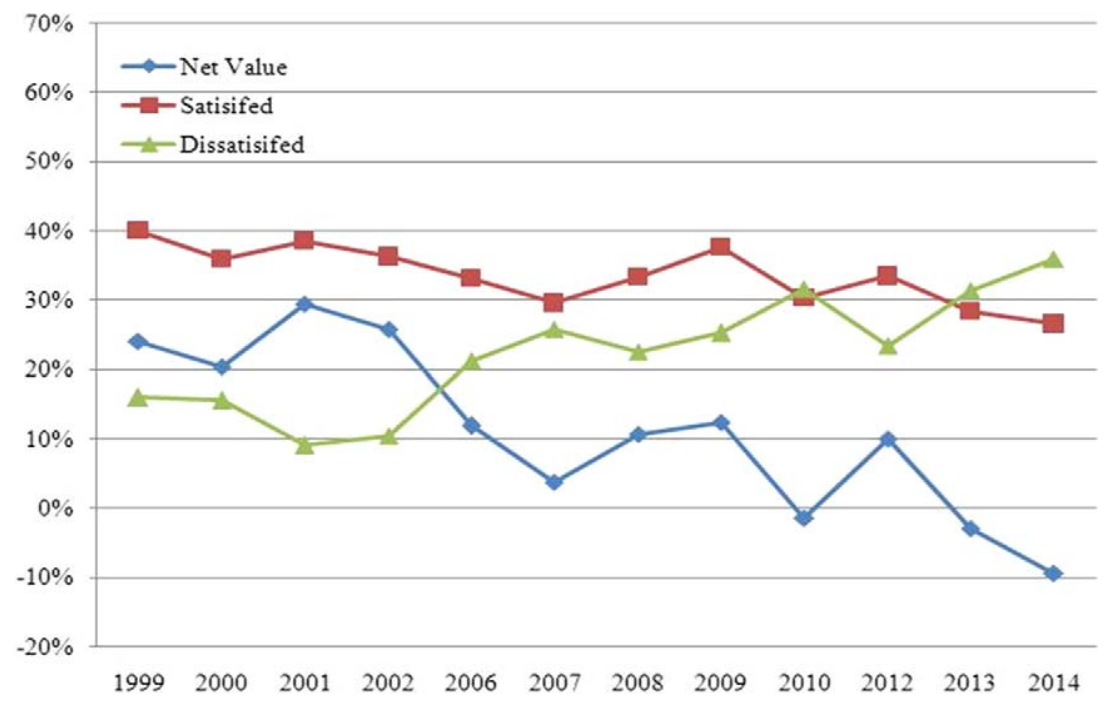

SOURCE: "Survey on Public Satisfaction with the Overall Performance of MSAR Government," Public Opinion Program, University of Hong Kong, December 19, 20I4, <http://hkupop.hku.hk/chinese/ popexpress/macau/govSat/datatables.html>, accessed December 20, 2014.

NOTE: Data for 2003-2005 and 20II are not available.

MSAR government's performance in the pace of democratic development from 2000 to 20I4. Overall, the Macao people were increasingly dissatisfied. In 20I4, this net value also broke a record, falling to $-9.4 \%$. In a 20I5 survey overall net satisfaction had returned to positive territory, at $\mathrm{I} .6 \%$ (and it rose to $13.8 \%$ in 20I6), but satisfaction with democratic development was still in question.

As a hybrid regime, the political system of the MSAR combines both democratic and undemocratic elements. However, despite the existence of some democratic elements, the influence of ordinary citizens on politics is still very limited. Less than half of the seats in the legislature are democratically elected. The Legislative Assembly has three categories of members: I4 directly elected by all registered voters, I2 elected indirectly (through negotiation and compromise by pro-Beijing associations), and seven appointed by the chief executive. ${ }^{61}$ In this executive-led system, the chief executive of

61. Eilo Wing Yat Yu, "Macao's 'One Country, Two Systems': High Autonomy or Intervention?" in Ray Yep, ed., Negotiating Autonomy in Greater China: Hong Kong and Its Sovereign before and after 1997 (Denmark: NIAS Press, 20I3): 207-4I, at 22I-23. 
Macao enjoys enormous constitutional power. Ironically, the chief executive has a much smaller degree of electoral representation and public mandate, because he is elected by a 400-member election committee highly influenced by the political elite and pro-Beijing forces. Then, ultimately, he is appointed by the Central People's Government. ${ }^{62}$

Macao can be considered a hybrid regime that leans toward the authoritarian side rather than the democratic, and has a long way to go in approaching full democracy. The fall of satisfaction in both overall performance and democratic development shows that the problem of declining legitimacy cannot be effectively dealt with by political marketing only. The continued poor performance of the MSAR government, such as corruption scandals and over-spending of public funds, has made the public increasingly aware of the need for structural reforms. As mentioned before, massive social movements such as the Labor Day protests in 2006 and 2007 under Ho's administration reliably indicate the sinking legitimacy of the MSAR government. The case of the welfare package for chief executives and principal officials (described below) was one of the landmark cases of Chui's first term that led to this public awakening. ${ }^{63}$ It highlighted the lack of authenticity of the political marketing strategies and the fact that improving government performance without institutional political reform was a false hope. The gap between the promises of political marketing and the actual performance of the government gradually evolved from low performance legitimacy (which emphasizes government performance) into procedural legitimacy (which concerns the procedures for choosing the government), as citizens questioned the capacity of the existing political institutions to deliver the performance they demanded.

\section{The Welfare Package for Chief Executives and Principal Officials}

The controversy surrounding the Welfare Package for Designated, Incumbent and Former Chief Executives and Principal Officials bill (hereafter, the welfare package) in May 20I4 illustrated how clearly the public realized that the widespread political marketing campaigns by Chui's administration amounted only to public relations and further exposed the problem of the structural legitimacy deficit. This welfare package was controversial in two

62. Ibid.

63. Ying Ho Kwong, "Protest against the Welfare Package for Chief Executives and Principal Officials: Macao's Political Awaking," China Perspectives 20I4:4 (20I4): 6I-65. 
major aspects. The first was the spending of public funds. The package proposed that former or retired chief executives should receive a monthly payment equal to $70 \%$ of their last monthly salary before leaving office. Antonio Ng Kuok-cheong, an opposition legislator, noted that Chui would receive more than MOP 6 million (US\$ 750,00o) if the bill was passed. The nine principal officials would be given one-off compensation of $14 \%$ (in the case of former civil servants) or $30 \%$ (for those from the private sector) of their monthly salary, to be multiplied by the number of months they had worked for the government. The provisions were retroactive to the year 2000, which meant that former chief executives and top officials would all enjoy the benefits. The second controversy was that the bill would give the chief executive immunity from criminal prosecution during his term of office.

The welfare package drew fierce opposition from society, particularly from the opposition camps and youth associations. The opposition claimed that the bill was tailor-made for the officials' own benefit and denounced it as selfserving. Even worse, this bill had been introduced without any public consultation. The chief executive's potential immunity from criminal charges sparked concerns that the head of the MSAR would be above the law. (The government has never explained why the chief executive should enjoy this privilege.) This welfare package made the public realize that the government was insincere about public consultation even in the case of a highly controversial issue, and showed that the problem of "black box operation," which dated back to the previous administration, remained unresolved. It convinced the public that the political marketing efforts of the MSAR government amounted to theater, bringing no real change and no true commitment from the government.

The widespread dissatisfaction and anger caused by the welfare package accumulated and grew quickly. On May 25, 20I4, about 20,000 Macao people marched to and protested at the government headquarters. (The police put the figure at only 7,00o.) It was regarded as the biggest demonstration since Handover. Protestors held signs and chanted slogans such as "Abuse of power," "The government neglects public opinion," and "Officials care for themselves" throughout the demonstration, urging the government to withdraw the package. That night, Florinda Chan Lai-Man, the secretary for administration and justice, released a statement that the government proposed that the bill should be "reanalyzed" in the Legislative Assembly. The organizers replied that they were urging retraction, not reanalysis, and 
threatened to organize another protest. Two days later, the activist group Macau Conscience estimated that 7,000 people answered their call to attend a sit-in protest to surround the Legislative Assembly (the police put the number at 4,900). Finally, all the legislators (except the president) attended a meeting that day and affirmed the request that the government restudy the bill. After that, Chui announced that he had decided to scrap the bill. ${ }^{64} \mathrm{He}$ further insisted that the government would advance with a new proposal "only with the people's agreement" and promised to use multiple channels such as media, lectures, explanatory sessions, and reflections from legislators to collect feedback. ${ }^{65}$

After this incident, Macau Conscience, the key organizer of the protest movement, declared that the welfare package protest campaign clearly exposed the problem of an undemocratic system in Macao. It declared that Macao needs a democratic system and universal suffrage to make a real accountable, transparent, and consultative government. In late August 20I4, Macau Conscience and two youth associations formed a joint committee and launched a civil referendum to understand public opinion on democracy. Drawing from the Occupy Central with Love and Peace June poll in 2014 in Hong Kong, the civil referendum asked the Macao people, "Do you want universal suffrage in the next Chief Executive Election?" and "Do you have confidence in Fernando Chui?" ${ }^{\prime 6}$ A total of 8,688 residents voted in the civil referendum. Of this number, $95 \%$ said yes to the first question, and $89 \%$ said no to the second. ${ }^{67}$ But despite this strong public disapproval, on August 3I, 20I4, Chui was re-elected, with $96 \%$ of the votes of the Election Committee.

The reaction to the welfare package demonstrated that the political marketing employed by Chui's government was a failure. Although he expended much effort to invent his political brands of "sunshine government" and "scientific administration," the gap between actual performance and public expectations remained. His administration ended up with even less legitimacy

64. Tou Ian Sio, "Lawmakers Propose to Discuss 'Golden Handshake' Bill Again," Macau Post Daily, May 26, 20I4, Po4.

65. Grace Yu, "Chui Withdraws Compensation Bill to 'Listen to the People," Macau Daily Times, May 30, 20I4, <http://macaudailytimes.com.mo/archive-2009-20I4/macau/53226-chuiwithdraws-compensation-bill-to-"listen-to-the-people".html>, accessed November 25, 2014.

66. Stuart Lau, "Macau Unofficial Democracy Poll Halted as Police Detain Five Activists," South China Morning Post, August 25, 2014, ED I.

67. Jeffie Lam, “9o pc Don't Trust Macau Leader, Says 'Referendum,"' South China Morning Post, September 3, 2014, City 3. 
than the previous administration. Also, the public had greater awareness of the structural problems of the non-democratic system in Macao, and voiced a stronger demand for democracy in society. Chui himself also paid a heavy political price in terms of his credibility and public image, making his efforts to govern much more difficult in his second term.

As long as this structural source of legitimacy deficit in Macao remains unsolved, any government's decision may rapidly lead to another political incident. Besides, the protest against the welfare package has finally evolved into a demand for democratization, which is a challenge to the legitimacy of the existing governing institutions. This clearly shows that the implications and impacts of the movement go beyond dissatisfaction with a particular policy or incident, and should be taken as a general democratic movement calling for more fundamental institutional changes. Without such a reform, it could be difficult to mitigate the root problem and it might not be long before dissatisfaction erupts over another unpopular policy.

In May 20I6, it was reported by the Chinese media that the MSAR government would donate RMB Ioo million (US\$ I4.7 million) through the Macao Foundation to Jinan University in Guangzhou to construct a media studies center and two Hong Kong-Macao student halls. The Macao Foundation was basically set up by the government in $200 \mathrm{I}$ and funded by $\mathrm{I} .6 \%$ of the gross revenues of Macao's casinos to subsidize community services. The MSAR government claimed that Macao had a patriotic responsibility to contribute to the country's development and to enhance education services in the motherland. But the opposition claimed that the Macao Foundation held a lot of public money and the subsidy application procedures were "black box-based." 68

A total of 17 groups called for a large-scale demonstration, with the aim of putting pressure on the Macao Foundation to withdraw the donation to Jinan University and urging the government to improve transparency and fulfill its promise of becoming a "sunshine government." Some groups also called for Chui's resignation because of the abuse of public funds. ${ }^{69}$ We can see that when Chui failed to fulfill his promises, negative rhetoric such as

68. "Groups Should Improve Transparency on Subsidies: FM Chief," Macau Post Daily, May 3I, 2016, Po2.

69. "Iоo Million Yuan Isn't Much for a University: Tam Groups Call for Axing of Donation to Jinan Uni," Macau Post Daily, May Io, 2016, Po2. 
"making fake promises" spread through the society and became a political burden on the MSAR government.

\section{CONCLUSION}

Although studies have substantiated the effect of political marketing in influencing elections and campaigns in Western democracies, ${ }^{70}$ it is still doubtful whether its effect can be as valid and significant when it is applied outside its original democratic context. Even so, it is increasingly common for hybrid or even authoritarian regimes to use political marketing strategies and techniques to enhance their legitimacy, narrowing the legitimacy gap. Recent literature has also shown that Chinese leaders have used political marketing to present a positive image to the people with the aim of sustaining the stability of the authoritarian regime in China.

This article presents political marketing from a comparative perspective to test whether it can be applied across regime types and political settings. It examines the relationship between political marketing and legitimacy in a non-democratic setting through a case study of Macao under the leadership of Fernando Chui, the chief executive of Macao, in his first term of office, to provide empirical findings and shed more light on this important question. Facing the decline of legitimacy left behind by Edmund Ho, the first chief executive of Macao, Chui, followed the governing logic and path of Chinese leaders to use political marketing to narrow the legitimacy gap, with a further hope of reducing the demand for structural political reforms. Employing the political brands of "sunshine government" and "scientific administration," Chui attempted to portray himself to both the Beijing government and the people of Macao as a capable leader. However, this political marketing did not reduce public dissatisfaction or reverse the declining legitimacy of the Macao government. Even worse, once public confidence in the promises made by Chui had been severely undermined by political controversies, including the welfare package for chief executives and principal officials, the structural crisis of legitimacy inherent in the MSAR political system finally erupted to bring a new wave of governance crisis. In the end, instead of the demand for structural political reforms fading, the demand for democracy in Macao actually increased. 
This article does not claim that political marketing is useless for the governing of a hybrid regime, but it does have its limitations. Referring to its origins, political marketing has been used mainly to facilitate communication and enhance the link between the elite and the public in the process of democratic government; it was never intended to replace the system of democracy. It mainly serves a complementary rather than a substituting function in a democracy. It would be overstretching the concept and creating an unrealistic expectation to argue that political marketing can completely compensate for the structural deficiencies of an authoritarian system and perfectly substitute for a democracy to bridge the legitimacy gap between the two.

Furthermore, using political marketing to replace political reforms in a society with a growing demand for democratization can easily exacerbate political instability, often in the form of non-institutional and contentious politics with a high level of state-society tension. Without political reforms, there is also a weak structural incentive for policymakers and bureaucrats to provide the characteristics and performance of a true democracy. Without the corresponding institutions and structures, promises of democratic elements made by a non-democratic government in the course of political marketing are difficult to fulfill. Empty promises can give rise to more public frustration and further impair legitimacy. A vicious cycle of undelivered promises and shrinking legitimacy will be formed if the pattern persists of relying solely on political marketing without implementing structural reforms.

The case of Macao shows that using political marketing to resolve a structural political problem in a hybrid regime can be a dead-end solution. A longterm and more reliable solution to the legitimacy problem in Macao would be the early implementation of comprehensive constitutional reforms, in particular universal suffrage for the chief executive election, which would give real choices to the people in the selection of their political leader. Without this step forward, the structural source of the legitimacy gap in Macao will remain a political challenge, and any government's maladministration may quickly lead to another serious governance crisis. 